\title{
Multi-AGC Kinase Inhibitor AT13148
}

National Cancer Institute

\section{Source}

National Cancer Institute. Multi-AGC Kinase Inhibitor AT13148. NCI Thesaurus. Code C101786.

An orally available, small molecule inhibitor of AGC group kinases, with potential antineoplastic activity. AT 13148 inhibits, in an ATP-competitive manner, the enzymatic activity of two AGC kinases, protein kinase B (PKB or AKT) and p70S6K which play key roles in the PI3K/PKB/mTOR signaling pathway. Blockade of this pathway leads to an inhibition of cell growth and the induction of apoptosis in susceptible tumor cells. $\mathrm{PI} 3 \mathrm{~K} / \mathrm{PKB} / \mathrm{mT}$ OR pathway is dysregulated in greater than $50 \%$ of tumors, and is often correlated with resistance and increased tumor survival. AGC group kinases are serine/threonine kinases that are regulated by secondary messengers such as cyclic AMP and lipids. 